\title{
Peningkatan Keterampilan Motorik Halus Melalui Kegiatan Membatik
}

\author{
Winarsih \\ KB TK Aisyiyah Cipayung, Jakarta Timur \\ E-mail: wiwinf2@yahoo.co.id
}

\section{Article Info}

Received December 2018 Accepted Februari 2019

Published April 2019

\section{Keywords:}

Fine motor skills, batik activities, early childhood

\begin{abstract}
The purpose of this study to describe the process and learning outcomes through the implementation of batik activities that can improve fine motor skills of children in group A kindergarten Aisyiyah Bustaanul Athfaal Ciracas, East Jakarta, Year 2015/2016. The subjects of this study were 10 children. The research method used is based upon the model of action research which consists of four phases, including planning, action, observation and reflection. The study consisted of two cycles where each cycle consists of eight meetings. Data analysis techniques used in this research is the analysis of qualitative and quantitative data. Analysis of qualitative data by data reduction, data display and data verification. Quantitative data analysis with descriptive statistics that compare the results obtained from pre-action, the first cycle and the second cycle. The results of this study showed an increased fine motor skills through activities batik, can be proved by the average level of performance development (TCP) fine motor skills of children in pre-action amounted to 21 increased in the first cycle and the second cycle to 34 to 44.
\end{abstract}

\begin{abstract}
Abstrak: Tujuan penelitian ini untuk mendeskripsikan proses dan hasil pembelajaran melalui pelaksanaan kegiatan membatik yang dapat meningkatkan keterampilan motorik halus anak kelompok A TK Aisyiyah Bustaanul Athfaal Ciracas Jakarta Timur, Tahun 2015/2016. Subyek penelitian ini berjumlah 10 anak. Metode penelitian yang digunakan adalah action research yang terdiri dari eresearch mpat tahap yakni: perencanaan, tindakan, pengamatan dan refleksi. Penelitian ini terdiri dari dua siklus dimana masing-masing siklus terdiri dari delapan kali pertemuan. Teknik analisis data yang digunakan dalam penelitian ini adalah analisis data kualitatif dan kuantitatif. Analisis data kualitatif dengan cara reduksi data, display data dan verifikasi data. Analisis data kuantitatif dengan statistik deskriptif yaitu membandingkan hasil yang diperoleh dari pra tindakan, siklus pertama dan siklus kedua. Hasil penelitian ini menunjukkan adanya peningkatan keterampilan motorik halus anak melalui kegiatan membatik, dapat dibuktikan dengan rata-rata tingkat capaian perkembangan (TCP) motorik halus anak pada pra tindakan sebesar 21, mengalami peningkatan pada siklus I menjadi 34 dan siklus II menjadi 44.
\end{abstract}

Kata Kunci: Keterampilan motorik halus, kegiatan membatik, anak usia dini 


\section{PENDAHULUAN}

Pendidikan yang diberikan pada anak usia dini mengalami pertumbuhan dan perkembangan baik secara fisik, sosial emosional, bahasa dan kognitif semuanya saling berkaitan. Dengan demikian pendidikan pada anak usia dini diberikan sejak dini untuk mengembangkan segala aspek yang ada pada diri anak supaya dapat tumbuh dan berkembang secara maksimal. Pada masa ini anak mengalami pertumbuhan dan perkembangan yang luar biasa baik dari segi kognitif, fisik, sosial emosional, perkembangan fisik antara lain perkembangan motorik kasar dan motorik halus.

Perkembangan motorik halus pada bayi dan anak usia dini merupakan hal yang sangat penting. Anak belajar membutuhkan tangan dengan baik agar dapat menggerakkan mainan, keterampilan hidup misalnya makan dan memakai pakaian sendiri. Mereka belajar mengkoordinasikan mata dan tangan sehingga dapat menggunakan berbagai macam permainan.

Keterampilan motorik halus sebagai suatu keterampilan yang membutuhkan kontrol yang kuat terhadap otot khususnya yang termasuk dalam koordinasi tangan mata dan keterampilan yang membutuhkan ketepatan tinggi seperti menulis, mengetik, menggambar, menggunting, dan memasangkan kancing baju. Jika anak usia dini telah mampu melakukan gerakan motorik halus dengan baik, mereka akan terbiasa dalam segala kegiatan yang membutuhkan tangan dan jemari sehingga mereka akan mandiri dan bisa belajar menerapkan kemampuannya dalam kehidupan sehari-hari.

Berdasarkan penelitian yang dilakukkan Memisevic, \& Hadzic (2013), dalam jurnal " Education and Rehabilitation Center "Mjedenica" Sarajevo, Bosnia and Herzegovina, tentang "Development of fine motor coordination and visual motor integration in preschool children", hasil penelitian menjelaskan bahwa keterampilan motorik halus adalah hal yang sangat penting dalam perkembangan anak. Penelitiannnya ditujukan pada anak-anak yang mengalami keterlambatan pada perkembangan motorik halus, yang berisikan program rehabilitas untuk meningkatakan keterlambatanah motorik halus, sehingga anak-anak tidak mengalami resiko keterlambatan perkembangan motorik halus. 
Selanjutnya penelitian yang dilakukan Brown (2010),tentang "Improving fine motor skills in young children an intervention study", mengatakan bahwa penelitian yang dilakukannnya adalah eksperimen dari program gerakan primer pada anak laki-laki dan anak perempuan, percobaan program gerakan primer memiliki efek signifikan pada peningkatan keterampilan motorik halus anak usia sekolah dasar bila dibandingkan dengan intervensi kontrol gerakan, program gerakan dapat memiliki efek positif pada keterampilan motorik pada anak.

Untuk penelitian yang dilakukan oleh, Libertus, et, all (2014), “ Limited Fine Motor dan Grasping Skills in 6 moth old infants at high risk for autism ", mengatakan bahwa percobaan pada bayi tentang kegiatan menggenggam yang merupakan kegiatan pada motorik halus yang sangat penting, dimana program ini ditujukan untuk mengurangi resiko bayi yang nantinya mengalami gejala autis. Pada penelitian ini berbeda dengan penelitian sebelumnya yang sudah dipaparkan diatas, yaitu menggunakan kegiatan membatik untuk meningkatkan keterampilan motorik halus pada anak usia 4-5 tahun, penelitian ini menstimulasi pada koordinasi mata tangan dengan kegiatan membatik seperti menebalkan, menjiplak, menggunting dan mewarnai, dengan membatik diharapkan perkembangan motorik anak dapat ditingkatkan.

Berdasarkan pengamatan awal di Tk Aisyiyah Bustaanul Athfaal kelompok A yang berjumlah 10 orang menunjukan bahwa motorik halus anak masih rendah, seperti 6 dari 10 anak atau $60 \%$ belum rapi dalam menggunting sesuai gambar, 4 dari 10 anak atau $40 \%$ belum rapi dan penuh dalam mewarnai gambar, 5 dari 10 anak atau $50 \%$ belum rapi dalam menjiplak gambar dan 5 dari 10 anak atau $50 \%$ belum rapi dalam menebalkan garis. Dari wawancara dengan kepala sekolah di TK Aisyiyah Bustaanul Athfaal Ciracas diperoleh informasi ada beberapa anak yang menunjukkan bahwa keterampilan motorik halusnya rendah dan kegiatan membatik sebagai media stimulasi motorik halus belum dilakukan di TK Aisyiyah Bustaanul Athfaal.

Keterampilan motorik anak akan berkembang pesat saat berumur 5 tahun seperti koordinasi tangan, lengan, dan jari semua bergerak di bawah perintah mata. Anak juga akan membuat kemajuan yang signifikan dalam hal kemampuan-kemampuan pada masa prasekolah, seiring dengan pekembangan fisik mereka akan lebih membuat tubuh mereka melakukan hal yang mereka inginkan. Anak-anak usia 5 tahun memiliki banyak tenaga seperti anak usia 4 tahun, tetapi keterampilan motorik halus dan kasar sudah mulai lebih terarah dan terfokus dalam tindakan mereka, selalu bergerak, tanpa kegiatan. Keterampilan motorik menjadi lebih diperhalus, kegiatan menulis, 
menggunting, menggambar dan melukis merupakan suatu kegiatan yang bisa dilakukan dengan baik.

Berdasarkan permasalahan yang terjadi pada kelompok A TK Aisyiyah Bustaanul Athfaal Ciracas di Tahun 2015/2016 ditemukan alternatif penyelesaian masalah yaitu menggunakan metode bermain. Salah satu kegiatan permainan yang diharapkan dapat merangsang keterampilan motorik halus anak yaitu kegiatan membatik.

Kegiatan membatik yang dilakukan adalah menebalkan, menggunting, menjiplak dan mewarnai motif gambar, kegiata membatik disini disesuaikan dengan perkembangan anak usia, dimana dengan kegiatan membatik ini maka keterampilan motorik halus anak dapat ditingkatkan.

\section{Keterampilan Motorik Halus}

Pada usia 0-8 tahun merupakan usia keemasan bagi anak dengan perkembangan mental maupun fisik yang berlangsung secara pesat khususnya pada anak usia 4-5 tahun. Pada anak usia 4 - 5 tahun memiliki perkembangan fisik motorik yang baik, perkembangan badan, otot kasar dan otot halus.

Menurut Papalia \& Feldman (2009), keterampilan motorik halus merupakan keterampilan-keterampilan fisik yang melibatkan otot halus serta koordinasi mata dan tangan. Adapun kegiatan motorik halus antara lain: mengancingkan baju, menggambar, serta koordinai mata dan otot halus. Seiring dengan perkembangan kemampuan motorik, anak-anak prasekolah secara terus menerus menggabungkan kemampuankemampuan yang sudah mereka miliki dengan kemampuan yang mereka dapatkan untuk menghasilkan kapabilitas yang lebih kompleks.

Magill (2001), mengatakan keterampilan motorik halus sebagai sebuah gerakan yang memerlukan kontrol otot-otot ukuran kecil untuk mencapai tujuan tertentu yang meliputi koordinasi mata tangan dan gerakan yang membutuhkan gerakan tangan atau jari untuk pekerjaan dengan ketelitian tinggi. Jadi keterampilan motorik halus meliputi penggunaan dan kontrol otot kecil seperti menggunting, menggambar, mewarnai dan lain-lain.

Berdasarkan teori yang dikemukakan beberapa ahli di atas dapat disimpulkan bahwa keterampilan motorik halus adalah gerakan yang melibatkan bagian-bagian tubuh tertentu seperti tangan dan jemari khususnya koordinasi mata dan tangan yang 
dipengaruhi oleh kesempatan untuk belajar dan berlatih seperti kelenturan, koordinasi mata dan tangan.

\section{Membatik}

Batik adalah salah satu cara pembuatan bahan pakaian. Selain itu batik bisa mengacu pada dua hal, yaitu pertama adalah teknik pewarnaan kain dengan menggunakan malam untuk mencegah pewarnaan sebagaian dari kain. Dalam literatur internasional, teknik ini dikenal dengan sebagai wax-resist dyeing. Pengertian kedua adalah kain atau busana yang dibuat dengan teknik tersebut, termasuk penggunaan motif-motif tertentu yang memiliki kekhasan. Batik indonesia, sebagai keseluruhan teknik, teknologi, serta pengembangan motif dan budaya yang terkait, oleh UNESCO telah ditetapkan sebagai warisan kemanusiaan yang budaya lisan dan nonbendawi / masterpieces of the oral and intangible heritage of humanity, sejak 2 Oktober 2009.

Menurut Wulandari \& Nusantara (2011), batik sebagai suatu teknik atau proses dari proses penggambaran motif sampai pelorodan, sebagai ciri khas batik adalah cara penggambaran motif pada kain yang menggunakan proses pemalaman yaitu menggoreskan malam atau lilin yang ditempatkan pada wadah yang bernama canting dan cap.

Kegiatan membatik adalah proses penggambaran motif atau menjiplak pada kain atau mori sebagai ciri khas batik, proses pemalaman yaitu menggoreskan malam atau lilin pada pinggir motif, dan pencelupan / pewarnaan yang menghasilkan motif yang halus yang dikerjakan oleh tangan dan memerlukan koordinasi mata dan tangan.

\section{METODE}

Dalam penelitian ini digunakan metode penelitian tindakan (Action Reserch) untuk mendapatkan hasil yang akurat. Teknik pengumpulan data yang digunakan dalam penelitian ini adalah catatan observasi, wawancara, dan dokumentasi. Catatan observasi terdiri dari apa yang dilihat, didengar, dan dipikirkan oleh peneliti dalam rangka mengumpulkan data. Instrumen yang digunakan melalui defenisi konseptual dan operasional yang menjelaskan bahwa keterampilan motorik halus adalah gerakan yang melibatkan bagian-bagian tubuh tertentu khususnya koordinasi mata dan tangan yang dipengaruhi oleh kesempatan untuk belajar dan berlatih seperti kelenturan, koordinasi mata dan tangan, kecepatan dn ketepatan. 
Analisis data yang yang digunakan adalah analisis data kualitatif dengan cara menganalisis data dari hasil catatan observasi, wawancara dan dokumentasi serta langkah-langkah reduksi data, display data, dan verifikasi data. Sedangkan analisis kuantitatif dengan statistik deskriptif yaitu persentase data tabel dan grafik yang diperoleh dari pra tindakan, siklus pertama dan siklus kedua.

\section{HASIL DAN PEMBAHASAN}

Hasil penelitian menunjukkan bahwa keterampilan motorik halus anak kelompok A TK Aisyiyah Bustaanul Athfaal Ciracas tahun ajaran 2015-2016 meningkat dari pratindakan sampai siklus II, disajikan dalam bentuk grafik sebagai berikut:

\section{Pra Tindakan}

Asesmen awal ini dilakukan untuk mengetahui kondisi awal keterampilan motorik halus anak kelompok A TK Aisyiyah Bustaanul Athfaal Ciracas tahun ajaran 2015-2016. Hasil asesmen awal untuk kemampuan motorik kasar anak disajakan dalam bentuk grafik sebagai berikut:

Data hasil asesmen keterampilan motorik halus anak disajikan dalam grafik sebagai berikut:

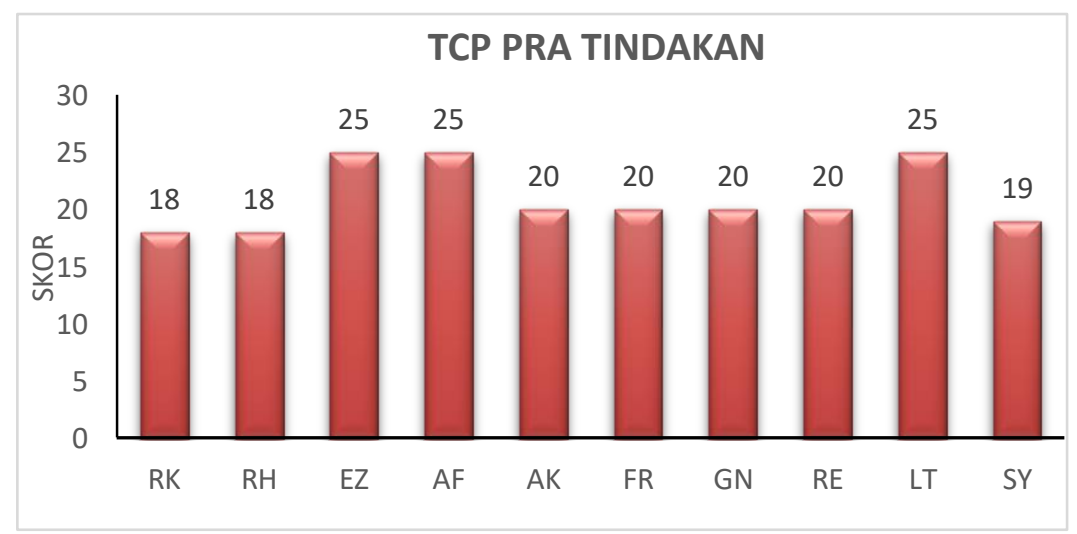

Grafik 1. Data Hasil Asesmen PraTindakan Keterampilan Motorik Halus Anak Kelompok A TK Aisyiyah Bustaanul Athfaal Ciracas 2015/2016

Berdasarkan tabel dan grafik di atas dapat dijelaskan bahwa rata-rata tingkat capaian perkembangan (TCP) keterampilan motorik halus anak kelompok A TK Aisyiyah Bustaanul Athfaal sebesar 21 dan berada pada kategori mulai berkembang (MB). Anak yang memperoleh TCP tertinggi ada 3 orang yaitu AF,LT dan EZ dengan nilai TCP 21 masih termasuk dalam kategori MB ( Mulai Berkembang) tetapi belum 
memenuhi kriteria keberhasilan tingkat capaian perkembangan yang disepakati kolaborator yaitu dengan nilai TCP 48 .

\section{Siklus I}

Observasi pada siklus I dilakukan untuk mengetahui skor yang diperoleh anak setelah pelaksanaan kegiatan membatik dalam meningkatkan keterampilan motorik halus. Data observasi dari pra tindakan sampai siklus 1 dapat dilihat pada grafik 2 berikut:

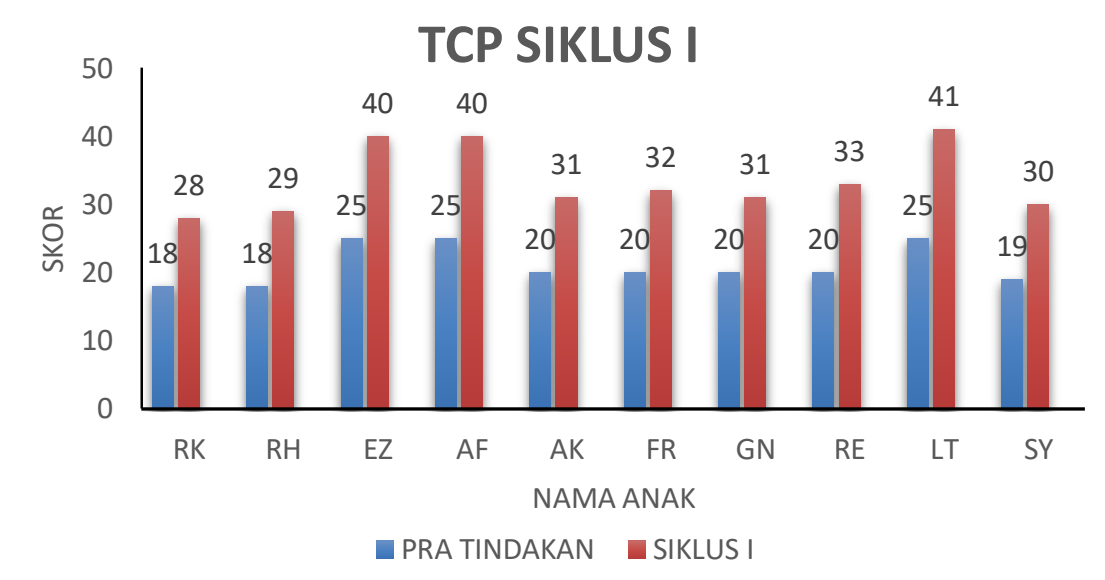

Grafik 2. Data Hasil Asesmen Keterampilan Motorik Halus PraTindakan sampai Siklus I pada Anak Kelompok A TK Aisyiyah Bustaanul Athfaal Ciracas 2015-2016

Tabel dan grafik di atas menunjukkan bahwa keterampilan motorik halus anak mengalami peningkatan setelah diberi tindakan kegiatan membatik. Rata-rata tingkat capaian perkembangan (TCP) anak pada pra tindakan sebesar 21 yang berada pada kategori mulai berkembang (MB) mengalami peningkatan menjadi sebesar 34 yang berada pada kategori berkembang sesuai harapan (BSH) pada siklus 1.

Pada tabel dan grafik juga dapat dijelaskan bahwa rata-rata semua anak mengalami peningkatan dari pra tindakan ke siklus 1, di Siklus I ini terdapat 3 anak yang termasuk kategori berkembang sangat baik (BSB) yaitu EZ, AF dan LT, untuk berkembang sesuai harapan terdapat 7 anak yaitu RK, RH,AK,FR, GN, RE dan SY.

Berdasarkan kriteria keberhasilan, penelitian ini dikatakan berhasil jika minimal 71\% dari jumlah anak yaitu 7 dari 10 anak mencapai TCP minimal yang ditentukan bersama dengan kolaborator. TCP minimal yang ditentukan sebesar 75\% dari TCP maksimal yaitu 48 . 
Peneliti dan kolaborator mengamati peningkatan yang terjadi pada tiap indikator untuk melihat sejauh mana peningkatan pada masing-masing indikator. Berikut ini hasil asesmen keterampilan motorik halus anak pada masing-masing indikator dari pra tindakan sampai siklus I.

\section{Siklus II}

Observasi pada siklus II dilakukan untuk mengetahui skor yang diperoleh anak setelah pelaksanaan kegiatan membatik dalam meningkatkan keterampilan motorik halus. Data observasi dari pra tindakan sampai siklus II dapat dilihat pada grafik berikut:

Data hasil asesmen tingkat capaian perkembangan (TCP) keterampilan motorik halus anak disajikan dalam bentuk grafik sebagai berikut:

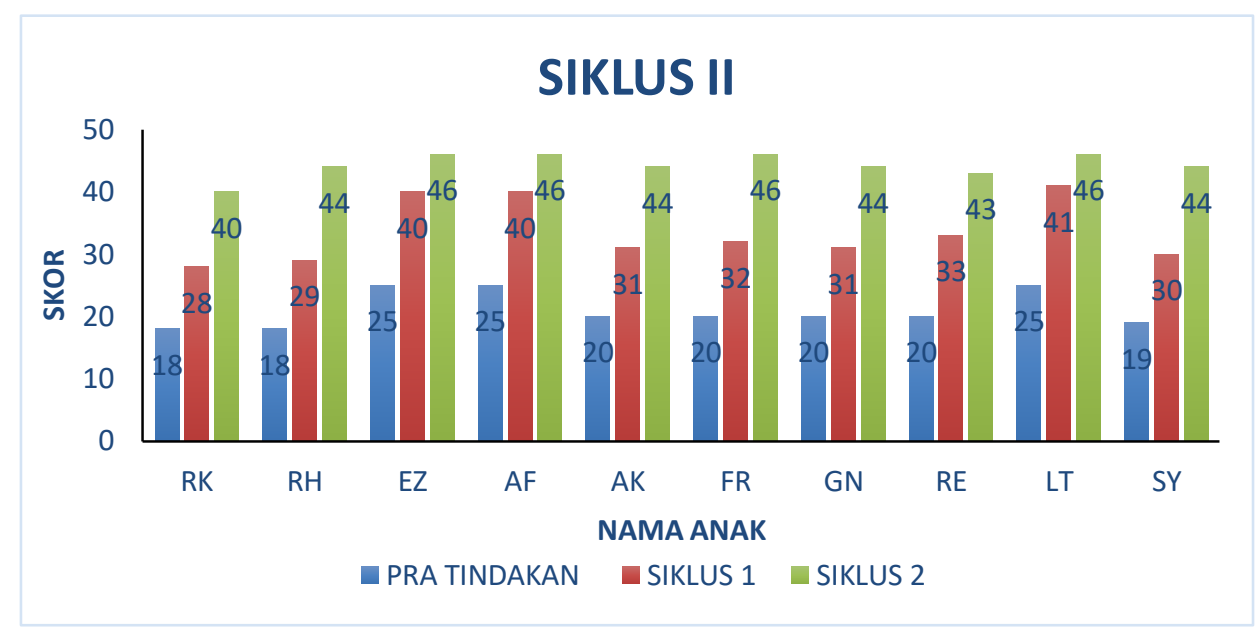

Grafik 3. Data Hasil Asesmen Keterampilan Motorik Halus pada Siklus I sampai Siklus II pada Anak Kelompok A TK Aisyiyah Bustaanul Athfaal Ciracas tahun 2015/2016

Tabel dan grafik di atas menunjukkan bahwa keterampilan motorik halus anak mengalami peningkatan setelah diberi tindakan yaitu kegiatan membatik. Rata-rata tingkat capaian perkembangan (TCP) anak pada pra tindakan sebesar 21 dan pada siklus I sebesar 34 mengalami peningkatan pada siklus II sebesar 44. Berdasarkan kategori yang ditentukan sebelumnya, rata-rata tingkat capaian perkembangan (TCP) anak pada siklus II termasuk dalam kategori berkembang sangat baik (BSB).

Tabel dan grafik di atas dapat dijelaskan bahwa setelah diberi tindakan pada siklus II, seluruh jumlah anak yaitu 10 telah mencapai tingkat capaian perkembangan 
(TCP) yang disepakati oleh peneliti dan kolaborator dengan kategori berkembang sangat baik (BSB) yaitu RK ,RH, EZ, AF, AK , FR, GN, RE, LT, SY, dari 10 anak tersebut yang paling besar nilai TCP adalah AF, LT, EZ dan FR sebesar 46, dan nilai yang paling kecil pada TCP anak adalah RK dengan nilai 40.

Kriterian capaian keberhasilan yang telah disepakati pada awal penelitian oleh peneliti dan kolaborator ditentukan bahwasannya 75\% dari jumlah anak yaitu 8 dari 10 anak mencapai tingkat capaian perkembangan (TCP) minimal sebesar 36 dari TCP maksimal 48. Hal tersebut membuktikan bahwa penelitian ini dikatakan berhasil meningkatkan keterampilan motorik halus anak karena mencapai TCP yang telah ditentukan. Hasil penelitian dapat disimpulkan bahwa keterampilan motorik halus kelompok A TK Aisyiyah Bustaanul Athfaal Ciracas tahun 2015/2016 dapat meningkat melalui kegiatan membatik.

\section{Pembahasan}

Hasil yang didapat dari intervensi yang dilakukan pada dua siklus tersebut merupakan hasil peningkatan terhadap keterampilan motorik halus anak melalui kegiatan membatik yang diperoleh berdasarkan analisis data kuantitatif dan kualitatif yang didapatkan di lapangan sebelum dan setelah dilaksanakan tindakan.

Berdasarkan pemerolehan data secara kualitatif dan kuantitatif, penelitian ini telah membuktikan bahwa kegiatan membatik terbukti dalam meningkatkan keterampilan motorik halus pada anak kelompok A di TK Aisyiyah Bustaanul Athfaal Ciracas tahun 2015-2016.

Pelaksanaan siklus II anak sudah menunjukkan peningkatan keterampilan motorik halus dengan rata-rata tingkat capaian perkembangan (TCP) 44 dari TCP maksimal 46. Tingkat capaian perkembangan (TCP) pada indikator menggunting 5,9 dari TCP maksimal 6, indikator menebalkan gambar pada garis 5,8 dari TCP maksimal 6, indikator menjiplak bentuk 5,8 dari TCP maksimal 6, indikator mewarnai gambar 5,8 dari TCP maksimal 6.

Penelitian ini dinyatakan berhasil karena telah mencapai kriteria keberhasilan yang ditentukan yaitu $71 \%$ dari jumlah anak yaitu 7 dari 10 anak mencapai tingkat capaian perkembangan (TCP) minimal 75\% dari TCP maksimal 48 yaitu sebesar 36 . Hal ini membuktikan bahwa pelaksanaan kegiatan membatik dapat meningkatkan keterampilan motorik halus pada anak kelompok A TK Aisyiyah Bustaanul Athfaal Ciracas Jakarta Timur 2015/2016. 
Hasil penelitian menunjukkan bahwa terdapat peningkatan keterampilan motorik halus anak dari siklus I ke siklus II. Berdasarkan hasil analisis data kuantitatif, rata-rata tingkat capaian perkembangan (TCP) keterampilan motorik halus anak pada pra tindakan 21 mengalami peningkatan pada siklus I menjadi 34 dan meningkat pada siklus II menjadi 44. Hal ini membuktikan bahwa pelaksanaan kegiatan membatik dapat meningkatkan keterampilan motorik halus anak.

Berdasarkan uraian yang telah dipaparkan dapat disimpulkan bahwa kegiatan membatik dapat meningkatkan keterampilan motorik halus anak. Hasil dari peningkatan keterampilan motorik halus anak melalui pelaksanaan kegiatan membatik dapat dikaji dengan pendekatan multidisipliner yang memiliki keterkaitan dengan beberapa bidang ilmu lain seperti: pendidikan, seni, budaya, psikologi, dan sosiologi.

Berikut dapat digambarkan pada bagan dibawah ini:

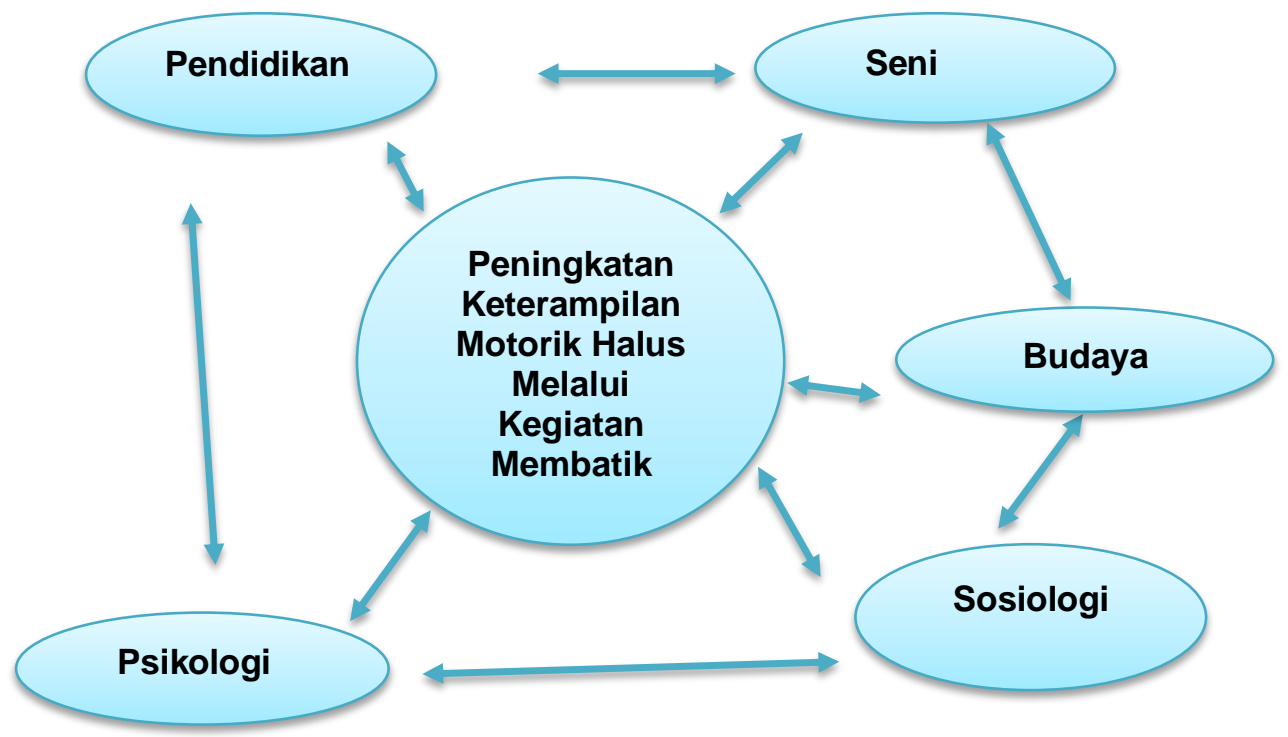

Gambar 1. Pendekatan Multidisipliiner Motorik Halus dengan kegiatan membatik

Di dalam kegiatan membatik merupakan kegiatan yang menyenangkan dan sesuai dengan dunia anak. Kegiatan membatik merupakan kegiatan yang bisa dilakukan oleh anak, karena di dalam kegiatan membatik terdapat menebalkan, menggunting, menjiplak dan mewarnai yang merupakan kegiatan yang menarik bagi anak, dengan demikian anak lebih mudah menerima apa yang disampaikan oleh guru. Dengan membatik, anak-anak diajarkan untuk memecahkan suatu masalah dan diajarkan mandiri dalam suatu kegiatan. 
Di dalam kelas, anak bersama-sama dengan temannya belajar dibimbing oleh gurunya dalam mempelajari suatua hal yaitu membatik, berinteraksi dengan gurunya, memperhatikan proses membatik yang diterangkan gurunya, bertanya dan meminta bantuan dengan gurunya, yang semuanya adalah interaksi dalam menyelesaikan suatu kegiatan yang dikerjakan secara bersama-sama di dalam kelas.

Kegiatan membatik merupakan kegiatan yang memerlukan komunikasi baik antara anak dengan anak ataupun anak dengan guru. guru selalu mengkomunikasikan kegiatan membatik ini dengan jelas, dari kegiatan pembuka, kegiatan inti sampai dengan kegiatan penutup. Pada kegiatan pembuka guru mengkomunikasikan apa yang akan dilakukan pada kegiatan membatik pada setiap pertemuan, kegiatan inti guru mengkomunikasikan apa yang harus dilakukan, tahapan, cara dalam kegiatan membatik, dan pada kegiatan penutup guru mengkomunikasikan tentang nilai-nilai yang terkandung pada sebuah kegiatan.

Menurut Seefeldt \& Wasik (2008), seni adalah dasar, karena dengan seni mengungkapkan perasaan dan emosi dengan cara aman, menguatkan koordinasi motor tangan mata, mengembangkan kemampuan pespektif, merasa diberi kesempatan memili dan memecahkan masalah dan menyadari akan timbulnya gagasan. Dalam hal seni, sangatlah jelas dengan membatik, seni anak akan terstimulasi, tujuan berseni pada anak adalah agar anak dapat mengungkapkan perasaan, ide dan pikiran serta angan-angan tentang diri dan lingkungannya. Dengan seni, perasaan dan kepekaan anak distimulasi dengan baik, peka dengan lingkungannnya, perasa dengan apa yang terjadi pada lingkungn sekitarnya, ide-ide positif keluar dalam diri anak, dapat mengungkapkan perasaannya dengan mewarnai, melatih kesabaran dalam menggunting dan memiliki seni yang baik dalam memilih warna yang disukai dalam hal menebalkan garis.

\section{KESIMPULAN}

Berdasarkan pada temuan saat penelitan di TK Aisyiyah Bustaanul Athfaal, maka hasil penelitian dapat disimpulkan sebagai berikut:

1. Proses kegiatan meningkatkan keterampilan motorik halus melalui kegiatan membatik yang dilaksanakan pada kelompok A di TK Aisyiyah Bustaanul Athfaal tahun 2015-2016. 
2. Dikatakan berhasil, didukung dari hasil analisis data pada pra siklus dengan perolehan persentase rata-rata TCP sebesar 21, pada siklus I sebesar 34 dan pada siklus II menjadi 44.

\section{Saran}

Selama penelitian ini dilakukan di TK Aisyiyah Bustaanul Athfaal Ciracas, peneliti dapat memberikan rekomendasi sebagai berikut:

1. Bagi guru Paud harus lebih kreatif dalam menstimulasi motorik halus anak usia dini salah satunya dengan kegiatan membatik.

2. Bagi orang tua, diperlukan keterlibatan orang tua dalam meningkatkan keterampilan motorik halus sangat diperlukan. Hal ini didasarkan bahwa keterampilan motorik halus tidak dapat dipisahkan dari kehidupan manusia sejak lahir.

\section{DAFTAR PUSTAKA}

Ari, W., \& Nusantara, B. (2011). Makna Filosofis, Cara Pembuatan dan Industri Batik. Yogyakarta: Penerbit Andi.

Brown, C. G. (2010). Improving fine motor skills in young children: an intervention study. Educational Psychology in Practice, 26(3), 269-278.

Libertus, K., Sheperd, K. A., Ross, S. W., \& Landa, R. J. (2014). Limited fine motor and grasping skills in 6-month-old infants at high risk for autism. Child development, 85(6), 2218-2231.

Magill, Ricard. (2001). Motor Learning, Conceps And Application. Boston Mc Graw Hill.

Memisevic, H., \& Hadzic, S. (2013). Speech and language disorders in children with intellectual disability in Bosnia and Herzegovina. Disability, CBR \& Inclusive Development, 24(2), 92-99.

Papalia, D. E., Olds, S. W., \& Feldman, R. D. (2009). Human development edisi 10. Jakarta: Salemba Humanika.

Seefeldt, C., \& Wasik, B. A. (2008). Pendidikan anak usia dini. Jakarta: PT Indeks. 